\title{
MANAJEMEN LEMBAGA PENDIDIKAN ISLAM NON FORMAL "SATU ATAP" AL HIDAYAH JURANGGUNTING ARGOMULYO KOTA SALATIGA
}

\author{
Puspo Nugroho \\ IAIN Kudus, Jawa Tengah, Indonesia \\ pusponugroho9@gmail.com
}

\begin{abstract}
Abstrak
Kajian penelitian ini bertujuan untuk mengungkap bagaimanakah pelaksanaan manajemen lembaga pendidikan Islam Nonformal, faktor pendukung dan penghambat serta langkah yang diambil dalam rangka pengembangan manajemen kelembagaan. Lokus penelitian ini di lembaga Pendidikan Islam nonformal Satu Atap Al Hidayah di Ledok Kecamatan Argomulyo Kota Salatiga. Pada prosesnya penelitian ini menggunakan pendekatan kualitatif dengan memakai teknik snowball sampling. Analisis data menggunakan Model Analisis Interaktif Miles \& Huberman yang meliputi kegiatan: (1) reduksi data, (2) penyajian data, dan (3) penarikan simpulan dan verifikasi. Hasil yang didapatkan bahwa pelaksanaan manajemen dikelola oleh ketua ketua beserta sekretaris, bendahara dan masing-masing kepala lembaga. Pelaksanaan fungsi manajerial belum sepenuhnya berjalan. Kendala utama diantaranya kurangnya dukungan pendanaan, kurang konsistennya perhatian takmir masjid, mlemahnya dukungan masyarakat serta peralihan status pengurus dari singgel menjadi keluarga yang berdampak pada perubahan fokus pekerjaan, pindah domisili, dan faktor keluarga. Beberapa langkah yang diambil diantaranya melakukan restrukturisasi organisasi dan perumusan rencana penataan pendanaan, pengadaan SDM baru melalui kaderisasi dan menyusun tatakelola administrasi.
\end{abstract}

Kata Kunci : Manajemen. Lembaga Pendidikan Islam, Nonformal, Satu atap.

\begin{abstract}
Aims of this study is to reveal how the implementation of management of non-formal Islamic education institutions, supporting and inhibiting factors and steps taken in the framework of developing institutional management. The locus of this study was Al Hidayah One Roof Non-formal Islamic Education Institution in Ledok, Argomulyo SubDistrict, Salatiga City. In the process, this study used a qualitative approach using the snowball sampling technique. Data analysis uses the Miles \& Huberman Interactive Analysis Model which includes activities: (1) data reduction, (2) data presentation, and (3) drawing conclusions and verification. The results obtained show that management is managed by the chairman and secretary, treasurer and head of each institution. The implementation of managerial functions has not been fully implemented. The main constraints include the lack of funding support, the lack of consistent attention to mosque takmir, the weakening of community support and the transfer of management status from singgel to family which has an impact on changes in work focus, domicile, and family factors. Some of the steps taken include conducting organizational restructuring and formulating a funding arrangement plan, procuring new human resources through regeneration and compiling administrative governance.
\end{abstract}

Keywords: Management. Islamic Education Institutions, Non-formal, One-stop 


\section{A. Pendahuluan}

Pendidikan memiliki peranan yang sangat penting dan tidak bisa dipisahkan dari proses kehidupan manusia. Selama ada kehidupan manusia selama itu pulalah pendidikan akan terus ada dan berkembang hingga mencapai pada taraf idealnya. Eksistensi pendidikan menjadi tanggung jawab bersama seluruh lapisan masyarakat. Pendidikan adalah usaha bersama untuk mencapai tujuan yang dicita-citakan. Tiga pilar pendidikan mulai dari pendidikan keluarga, sekolah, dan masyarakat menjadi ujung tombak kemajuan bangsa. Mulai dari jenjang formal, nonformal ataupun informal dan tentunya masing-masing corak memiliki ciri khasnya tersendiri dan masing-masing jenjangnya memerlukan keseriusan dalam penanganan dan pengelolaanya.Sebuah lembaga pendidikan yang didukung dengan sistem manajemen dan tata kelola yang baik, terarah, terencana dan matang akan jauh berbeda dengan lembaga yang hanya berjalan asal-asalan, asal ada murid, asal ada guru, asal tidak kosong dan yang lainnya.

Indikator majunya sebuah bangsa dilihat dari bagaimana majunya pendidikan di negara tersebut. Dewasa ini setiap bangsa berlomba-lomba bagaimana membangun peradaban bangsanya melalui jalur pendidikan. Dengan pendidikan diharapkan akan lahir calon-calon birokrat, guru, sarjana dan orang-orang ahli pada bidangnya masingmasing yang tentunya dengan lahirnya tokoh-tokoh tersebut diharapkan akan memberikan sumbangsih bagi kemajuan negara. Pada akhirnya indikasi bangsa yang maju bisa dikatakan lahir dari peran besar keberadaan lembaga-lembaga pendidikan yang ada di negara tersebut.

Pada prinsipnya secara kelembagaan dilihat dari jalur pendidikan yang ada di Indonesia sebagaimana yang tertuang didalam undang-undang sistem pendidikan nasional nomor 20 tahun 2003 pasal 13 ayat 1 menyatakan bahwa pendidikan di Indonesia terbagi menjadi tiga jalur utama, yaitu formal, nonformal, dan informal yang satu dengan lainya saling melengkapi dan memperkaya. Sedangkan menurut jenjangnya, Pendidikan dibagi ke dalam empat jenjang, yaitu pendidikan anak usia dini, pendidikan dasar, pendidikan menengah, dan pendidikan tinggi.

Perbedaan dari ketiga jalur tersebut ialah khususnya pada pendidikan formal merupakan pendidikan yang pada prosesnya dilaksanakan di sekolah-sekolah dengan jenjang pendidikan yang jelas dan tersistematisasi mulai dari pendidikan dasar, pendidikan menengah, sampai pendidikan tinggi. Sedangkan pendidikan informal ialah 
pendidikan yang tidak terstruktur dan bersifat mandiri, biasanya berada di lingkungan keluarga dan masyarakat. Adapun terkait pendidikan non-formal sesuai dengan UU Sisdiknas diatas dan diperkuat oleh peraturan pemerintah nomer 17 tahun 2010 pasal 1 ayat 31 tentang pengelolaan dan penyelenggaraan pendidikan menyatakan bahwa pendidikan non-formal ialah jalur pendidikan diluar pendidikan formal yang dapat dilaksanakan secara terstruktur dan berjenjang(Nasional 2003). Pendidikan Islam memiliki peran yang sangat strategis bagi pembentukan karakter generasi bangsa.

Coombs sebagaimana dikutip oleh Kadir menjelaskan bahwa pendidikan nonformal merupakan sebuah aktifitas pendidikan yang dalam pelaksanaanya diatur di luar sistem pendidikan formal baik yang berjalan tersendiri ataupun sebagai suatu bagian yang penting dalam aktifitas yang lebih luas ditujukan untuk melayani sasaran didik yang dikenal dan untuk tujuan-tujuan pendidikan.(Kadir 1982:49)

Pada pelaksanaanya di lapangan, Pendidikan non-formal paling banyak terdapat pada jenjang usia dini, serta pendidikan dasar. Diantara beberapa contoh kelembagaan pendidikan non-formal adalah sepertihalnya TPQ, atau Taman Pendidikan Al Quran, Madrasah Diniyah Takmiliyah dan PAUD TPQ atau yang biasa disebut PAUD berbasis Al Qur'an, yang banyak terdapat di Masjid dan surau-surau atau mushola.

Dijelaskan dalam Peraturan Menteri Agama Republik Indonesia No 13 Tahun 2014 Tentang Pendidikan Keagamaan Islam tentang TPQ dan Madrasah diniyah Takmiliyah Non Formal ialah bahwa Diniyah takmiliyah yang selanjutnya disebut Madrasah Diniyah Takmiliyahadalah lembaga pendidikan keagamaan Islam pada jalur pendidikannonformal yang diselenggarakan secara terstruktur dan berjenjang sebagaipelengkap pelaksanaan pendidikan agama Islam pada jenjang pendidikandasar, menengah, dan tinggi (Peraturan Menteri Agama Republik Indonesia No 13 Tahun 2014 Tentang Pendidikan Keagamaan Islam n.d.). Sedangkan Taman Pendidikan AlQur'an adalah lembaga pendidikan keagamaan Islam yang bertujuan untuk memberikan pengajaran bacaan, tulisan, hafalan, dan pemahaman Al-Qur'an. Taman Pendidikan Al Qur'an adalah salah satu bentuk pendidikan Islam Nonformal yang ditujukan bagi anak-anak sejak lahir hingga usia 18 tahun yang berasal dari keluarga muslim dalam rangka menyiapkan generasi Qur'ani. Sedangkan PAUD berbasis TPQ adalah bentuk-bentuk pendidikan Anak usia Dini pada jalur pendidikan Nonformal yang dilaksanakan secara terintegrasi dengan taman pendidikan AL Qur'n.(Direktorat 
Pembinaan Pendidikan Anak Usia Dini-Direktorat Jenderal Pendidikan Anak Usia Dini, Non Formal dan Informal 2011:2)

Kemerosotan dalam hal pengelolaan lembaga pendidikan Islam Non Formal kiranya menjadi problem utama di berbagai daerah, begitupula di lembaga pendidikan Islam non-formal Satu Atap Al Hidayah. Hal ini sejalan dengan pendapatnya Mujahid, suatu ironi yang harus diakui umat Islam bersama luasnya konsep al-Qur'an tentang pendidikan adalah pelekatan identitas tertinggal, terbelakang dan miskin identitas. Ketertinggalan itu sedikitnya bisa dilihat dari eksistensi lembaga pendidikan Islam yang dulu memiliki peran strategis, kini antusias masyarakat untuk memasuki pendidikan Islam mengalami penurunan yang cukup drastis. Kecuali pada pesantren yang mampu melakukan adaptasi dengan perkembangan global(Damopolii 2015).

Hal ini seakan diamini oleh lembaga ini terbukti dengan prestasi yang begitu banyaknya hingga tingkat nasional pada ivent Festifal Anak Sholeh Indonesia lembaga ini kian lama dari fase ke fase justru memperlihatkan adanya indikasi melemah. Para pengajar seakan mengalami dehidrasi dan kehabisan amunisi yang berdampak pada semakin lama lembaga yang bisa dibilang sebagai tumpuan pendidikan masyarakat ini kurang mendapatkan perhatian baik masyarakat maupun pimpinan yang bertanggung jawab terhadap keberadaan lembaga tersebut dalam hal ini divisi pendidikan masjid Al Hidayah.

Pada penelitian ini memilih lokus penelitian di Lembaga Pendidikan yang dinaungi oleh Takmir masjid Al Hidayah Argomulyo Salatiga yang meliputi TPQ dan Madrasah Diniyah dan PAUD Berbasis Al Qur'an Al Hidayah yang masuk kategori Satuan PAUD Sejenis (SPS). Alasan yang mendasari pemilihan lokasi tersebut adalah ketiga lembaga tersebut berjalan dibawah naungan Takmir masjid Al Hidayah dengan dengan memberikan kewenangan penuh kepada pengelola untuk mengatur jalanya proses pendidikan. Tipe desentralisasi pendidikan menjadi sangat tampak ketika setiap kebijakan lembaga sendiri yang mengatur. Dalam pengelolaannya dijalankan secara "Satu Atap". Selain itu melihat konteks sosiologi masyarakat mayoritas sebagai karyawan pabrik mengingat lokasi tersebut berada dikompleks pabrik tekstil terbesar di kota Salatiga.

Tujuan kajian ini adalah ingin mengungkap bagaimanakah Pelaksanaan manajemen pengelolaan Lembaga?, faktor faktor apa sajakah yang menjadi pendukung dan penghambat?, serta bagaimanakah usaha atau langkah yang ditempuh dalam 
Pengembangan Managemen Pengelolaan Lembaga Pendidikan Islam Non-Formal Satu Atap Al Hidayah Juranggunting Salatiga?

Penelitian ini termasuk dalam jenis penelitian lapangan (field research) dalam pelaksanaanya menggunakan metode pendekatan kualitatif deskriptif analitis yang umumnya menggunakan strategi multi metode yaitu wawancara, pengamatan, serta penelaahan dokumen/ studi documenter yang antara satu dengan yang lain saling melengkapi, memperkuat dan menyempurnakan.(Nana Syaodih 2008:108) Data yang dimaksud berasal dari naskah wawancara, catatan lapangan, foto, videotape, dokumen pribadi, catatan atau memo dan dokumen lainnya.(Moleong, 2002:11)

Dalam prosesnya menggunakan teknik snowball sampling. Menurut Riyanto, snowball sampling, yaitu cara menggali sumber data atau informan lain, membandingkan dan mengecek ulang derajat kepercayaan data yang diperoleh dengan menggunakan sumber lain atau informan yang berbeda.(Riyanto 2007:18) Data dianalisis dengan Model Analisis Interaktif Miles \& Huberman yang meliputi kegiatan: (1) reduksi data (data reduction), (2) penyajian data (data display), dan (3) penarikan kesimpulan dan verifikasi.(Miles, M.B \& Huberman, A.M. 1992:16).

\section{B. Pembahasan}

\section{Sejarah Lembaga Pendidikan Islam Non Formal Al Hidayah}

Sejarah lahirnya lembaga pendidikan Islam non formal ini diawali dengan berdirinya Taman Pendidikan Al Qur'an Al Hidayah, Pendidikan Al-Hidayah merupakan lembaga pendidikan non formal yang dikelola dibawah divisi/seksi kependidikan ketakmiran masjid Al Hidayah. Awal mula berdirinya lembaga ini pada tahun 1998 dengan berdirinya diawali oleh lahirnya taman Pendidikan Al qur'an (TPQ). Mengingat masyarakat setempat mayoritas mata pencaharianya sebagai buruh pabrik dan banyaknya anak-anak muslim menjadi hal yang mendorong berdirinya dan pesatnya perkembangan Taman Pendidikan Al Qur'an Al Hidayah hingga melahirkan dua lembaga pendidikan selanjutnya yaitu PAUD Berbasis Al Qur'an dan Madrasah Diniyah Takmiliyah. Berbagai ajang kejuaraan dan prestasi baik tingkat desa, kecamatan, kota bahkan provinsi dan nasional pernah diikuti santriwan santriwati Al Hidayah. Hal tersebut menjadi salah satu yang mendorong BADKO Provinsi Jawa Tengah melalui rekomendasi Badan Koordinasi Taman Pendidikan AL Qur'an (BADKO TPQ) Kota Salatiga memberikan perhatian lebih sehingga pada awal tahun 2010 ditetapkan sebagai 
salah satu lembaga yang mendapatkan kesempatan sebagai pilot project bantuan pengembangan PAUD berbasis Al Qur'an atau biasa disebut PAUD-TPQ. Seiring perkembangannya pada tahun 2010 lahirlah dan beroperasilah PAUD berbasis $\mathrm{Al}$ Qur'an atau biasa disebut PAUD TPQ yang masuk pada kluster Satuan PAUD Sejenis (SPS).

Pada tahun yang selanjutnya tepatnya tahun 2011 oleh pengurus mencoba mengembangkan kelembagaannya ke jenjang yang lebih tinggi. Alasan mendasar yang mendorong pengembangan kelembagaan tersebut adalah keberlangsungan proses pendidikan santri pada jenjang usia TPQ keatas (pasca TPQ) dalam hal ini ketika anak-anak memasuki usia 11 tahun keatas rata-rata santri pasca lulus dari SD/MI seakan mulai enggan untuk belajar agama di TPQ, dengan alasan malu dan merasa sudah dewasa serta alasan lainya sehingga mendorong pengelola untuk mengembangkan kelembagaan dan mendirikan madrasah diniyah takmiliyah. Tujuan dari pendirian lembaga madrasah tersebut adalah untuk menfasilitasi, menampung para lulusan TPQ yang notaben-nya usia pubertas antara 11 sampai 15 tahun. Biasanya anak usia tersebut menduduki bangku sekolah menengah pertama (SMP/MTs) pada pendidikan formalnya.

Dari hasil observasi awal peneliti dilapangan terlihat sebuah bangunan fase atau jenjang pendidikan dari ketiga lembaga tersebut diawali mulai dari PAUD TPQ- TPQ-Madin. PAUD TPQ Al Hidayah dalam pelaksanaanya dikhususkan bagi anak anak usia dini usia 3 s.d 6 tahun. Pada jenjang TPQ terbagi menjadi beberapa kelas disesuaikan dengan kemampuan penguasaan anak terhadap ilmu $\mathrm{Al}$ Qur'an. Terlihat di lapangan mulai usia 7 s.d 11 tahun, pada pendidikan formal biasanya usia tersebut menduduki jenjang SD/MI kelas 1 s.d kelas 6, tentunya pengelompokan kelas pada jenjang TPQ ini juga mengacu dan mempertimbangkan aspek penguasaan seorang anak terhadap kemampuan membaca menulis huruf hijaiyah. Adapun pada jenjang madrasah diniyah lebih difokuskan pada anak-anak usia pasca TPQ yaitu usia anak memasuki pendidikan MTs/SMP rentang usia antara 12 s.d 15 tahun sebagai kelanjutan proses pendidikan di TPQ.

\section{Konsep Manajemen Lembaga Pendidikan Islam Non Formal}

Dalam KBBI, Manajemen adalah penggunaan sumber daya secara efektif untuk mencapai target. Sedangkan Pengelolaan memiliki beberapa arti diantaranya proses, cara, perbuatan mengelola; proses melakukan kegiatan 
tertentu dengan menggerakkan tenaga orang lain; proses yang membantu merumuskan dan tujuan organisasi; proses yang memberikan pengawasan pada semua hal yang terlibat dalam pelaksanaan dan pencapaian tujuan dan target.

Manajemen berasal dari bahasa latin dari kata "manus" yang artinya "tangan" dan "agere" yang berarti " melakukan". Kata-kata ini kemudian disatukan secara utuh menjadi "managere" yang bermakna menangani sesuatu, mengatur, membuat sesuatu menjadi seperti apa yang diinginkan dengan mendayagunakan seluruh sumber daya yang ada. Irawan mendefenisikan bahwa Pengelolaan memiliki arti yang sama dengan manajemen yaitu penggerakan, pengorganisasian dan pengarahan usaha manusia untuk memanfaatkan secara efektif material dan fasilitas untuk mencapai suatu tujuan.”(Irawan 1997:5)

Ditegaskan oleh James, "Management is a fundamental humam activitvity", maknanya bahwa Manajemen merupakan sebuah aktivitas manusia yang sangat mendasar (Donnelly. JR. 1981:1) Ibarat seorang arsitek bangunan dalam proses membuat rumah, managemen merupakan pondasi utamanya. Kokoh tidaknya bangunan yang dihasilkan sangat tergantung dari seberapa matang pondasi yang dibuatnya. Pondasi disini ialah management itu sendiri. Manajemen pendidikan merupakan serangkaian proses yang terdiri dari perencanaan, pengorganisasian, penggerakan dan pengawasan yang dikaitkan dengan bidang pendidikan (Hidayat and Machali 2012:5)

Antara manajemen dan pengelolaan merupakan sebuah kesatuan yang tidak bisa dipisahkan satu dan lainya. Dalam pengelolaan lembaga pendidikan sangat penting untuk menggunakan prinsip-prinsip manajemen sehingga lembaga pendidikan mampu menjalankan fungsinya dengan baik terlepas dari perbedaan jenis lembaga dan tujuan masing-masing lembaga pendidikan yang ada. Sehingga diharapkan dengan penggunaan prinsip-prinsip manajemen yang efektif dan efisien mampu mendorong tercapainya target yang dicanangkan dan tentunya akan memberikan kepuasan bagi pengguna lembaga pendidikan tersebut.

Manajemen menjadi penting dalam hal ini dan selaras dengan Maqolah"Al-haqqu bila nidhamin yaghlibuhul bathilu bi nidhamin”. Maqolah tersebut mengandung arti bahwa sebuah kebaikan yang tidak terorganisir akan dikalahkan oleh kejahatan yang terorganisir. Mengelola lembaga pendidikan menjadi sebuah ladang kebaikan. Mencermati maqolah diatas jelas bahwa 
pendekatan manajemen merupakan sebuah keniscayaan. Perlunya mengejawantahkan pepatah diatas pada bidang pendidikan Islam Non Formal, supaya kedepanya bisa menjadi baik dan sukses maka lembaga pendidikan Islam non formal perlu di tata kelola dan di organisir dengan baik.

\section{Fungsi dan peranan Manajemen Lembaga Pendidikan}

Pada dasarnya, dimanapun manajemen diterapkan memiliki fungsi yang sama. Apabila dikaji lebih dalam menurut pelaksanaannya, fungsi manajemen terbagi menjadi dua, yaitu fungsi manajemen secara makro dan fungsi manajemen secara mikro. Fungsi manajemen makro, seperti departemen dan dinas dengan melakukan fungsi manajemen secara umum. Sedangkan fungsi manajemen secara mikro, seperti halnya lembaga pendidikan yang lebih menekankan pada fungsi perencanaan, pengorganisasian, penggerakan atau motivasi dan kontrol (planning, organizing, actuating atau motivating, controling).

Menurut beberapa tokoh sebagaimana dikutip oleh Fathor Rohman dalam kajianya menjelaskan langkah-langkah dalam manajemen sebagai berikut (Rachman 2015:294):

Tabel 1. Tahap-Tahapan Manajemen menurut para Ahli

\begin{tabular}{|c|c|c|c|c|c|c|c|}
\hline 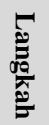 & Fayol & Gullick & Terry & Dale & $\begin{array}{l}\text { Koonts \& } \\
\text { O'donnel }\end{array}$ & Newman & Stoner \\
\hline 1 & Planning & Planning & Planning & Planning & Planning & Planning & Planning \\
\hline 2 & Organizing & Organizing & Organizing & Organizing & Organizing & Organizing & Organizing \\
\hline 3 & $\begin{array}{l}\text { Commanding } \\
\text { Coordinating }\end{array}$ & $\begin{array}{l}\text { Staffing } \\
\text { Directing } \\
\text { Coordinating }\end{array}$ & Actuating & $\begin{array}{l}\text { Staffing } \\
\text { Directing } \\
\text { Innovating } \\
\text { Representing }\end{array}$ & $\begin{array}{l}\text { Staffing } \\
\text { Directing }\end{array}$ & $\begin{array}{l}\text { Assembling } \\
\text { of } \\
\text { Resources, } \\
\text { Directing }\end{array}$ & Leading \\
\hline 4 & Controlling & $\begin{array}{l}\text { Reporting } \\
\text { Budgeting }\end{array}$ & Controlling & Controlling & Controlling & Controlling & Controlling \\
\hline
\end{tabular}


Menurutnya dari semua pendapat tokoh diatas yang menjelaskan terkait fungsi-fungsi manajemen terdapat persamaan yaitu pada langkah 1,2 dan 4 yaitu fungsi planning, organizing, dan controlling. Sedangkan pada langkah ke-3 meskipun muncul istilah yang berbeda-beda seperti fungsi actuating/staffing/leading namun pada prinsipnya mengandung substansi yang sama. Secara umum, perbedaan-perbedaan tersebut memiliki titik temu dalam menyebutkan fungsi-fungsi manajemen yaitu sebagai berikut.

\section{a. Perencanaan (Planning)}

Planning atau perencanaan merupakan fungsi manajemen yang paling awal dari keseluruhan fungsi manajemen. Perencanaan atau planning merupakan suatu kegiatan yang menyiapkan secara sistematis hal-hal yang akan dilakukan untuk mencapai tujuan tertentu. Mondy, Noe dan Premeaux (1993) sebagaimana dikutip oleh Kristiawan et.al menjelaskan bahwa perencanaan merupakan proses menentukan apa yang seharusnya dicapai dan bagaimana mewujudkannya dalam kenyataan.(Kristiawan, Safitri, and Lestari 2017:25)

Menurut Burhanuddin istilah perencanaan memiliki bermacam-macam pengertian diantaranya perencanaan sebagai suatu proses kegiatan pemikiran yang sistematis mengenai apa saja yang akan dicapai, apa saja yang harus dilakukan, langkah dan metode, proses kegiatan yang dibutuhkan untuk menyelenggarakan kegiatan pencapaian tujuan yang tersusun secara rasional, logis dan systematis serta berorientasi kedepan.(Burhanuddin 1994:167) Aspek perencanaan meliputi a) apa yang dilakukan, b) siapa yang harus melakukan, c) kapan dilakukan, d) di mana dilakukan, e) bagaimana melakukan, f) apa saja yang diperlukan agar tercapai tujuan secara maksimal.(Hidayat and Machali 2012:21)

\section{b. Pengorganisasian (organizing)}

Langkah manajemen selanjutnya adalah pengorganisasian. Pengorganisasian (organizing) merupakan langkah kedua dalam manajemen organisasi setelah perencanaan (planning). Esensi pengorganisasian adalah organisme yang membuat struktur organisasi atau lembaga hidup secara dinamis. Perencanaan yang matang tidak mungkin bisa berjalan maksimal tanpa didukung dengan pelaksana yang menjalankan dan menggerakkan pekerjaan. Pengorganisasian bisa diistilahkan sebagai urat nadi bagi keberlangsungan lembaga pendidikan. 
Pengorganisasian berasal dari kata organisasi yang memiliki makna sebuah "wadah" untuk mencapai tujuan. sesuai asal katanya organisasi berasal dari kata organum (yang berarti alat, bagian, atau badan), secara umum sering diartikan sebagai kumpulan orang dengan sistem kerja sama untuk mencapai tujuan bersama (Rachman 2015:230) Dibentuknya organisasi memiliki tujuan untuk mencapai hal-hal tertentu yang tidak mungkin dilaksanakan secara individual atau seorang diri.(Winardi 2006:1) Pengorganisasian merupakan proses membagi kerja ke dalam tugas-tugas kecil, membebankan tugas-tugas itu kepada orang sesuai dengan kemampuannya, dan mengalokasikan sumber daya, serta mengkoordinasikannya dalam rangka efektifitas pencapaian tujuan organisasi (Fatah 2012:71).

Berlangsungnya organisasi secara maksimal membutuhkan pengorganisasian yang baik yang didalamnya mencakup pembagian tugas dan pemberian wewenang dan tanggng jawab yang jelas dan rinci sesuai dengan bidang dan batasan kewenanganya. Dalam prosesnya pengorganisasian merupakan suatu tindakan menciptakan sinergitas hubungan yang terstruktur antara satu bagian dengan bagian yang lain yang terintegrasi dan saling mempengaruhi satu sama lainya. Proses pengorganisasian sebagaimana digambarkan oleh Ernest Dale (stoner,1996) sebagai berikut(Rachman 2015:312):

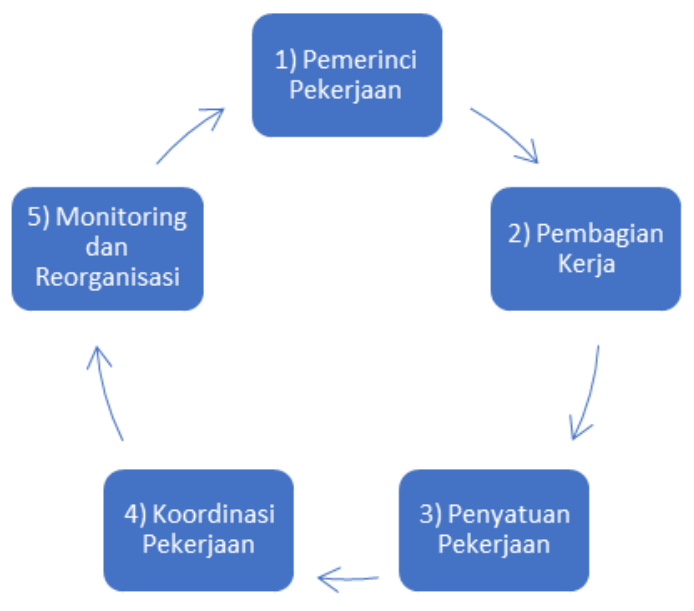

\section{Bagan 1. Proses Pengorganisasian menurut Ernest Dale}

Bisa diambil kesimpulan bahwa pengorganisasian adalah suatu proses dimana seorang leader atau pemimpin dalam menjalankan fungsi manajemen 
mencakup mengatur, membagi pekerjaan yang ditujukan pada sekelompok orang atau pegawai yang dalam pelaksanaaanya diberikan tanggung jawab dan wewenang dalam organisasi lembaga.

\section{c. Penggerakan (Actuating)}

Penggerakan atau actuating adalah salah satu dari beberapa fungsi manajemen yang memiliki tujuan untuk merealisasikan hasil planning dan organizing. Penggerakan atau dalam istilah asing sering disebut actuating adalah upaya menggerakkan atau mengarahkan tenaga kerja (man power) serta mendayagunakan fasilitas yang ada yang dimaksud untuk melaksanakan pekerjaan secara bersama.(Hidayat and Machali 2012:25)

Dalam sumber yang berbeda dijelaskan penggerakkan (actuating) adalah hubungan antara aspek-aspek individual yang ditimbulkan oleh adanya hubungan terhadap bawahan untuk dapat mengerti dan memahami pembagian pekerjaan yang efektif dan efisien.(Kristiawan, Safitri, and Lestari 2017:28) Menurut Kristiawan et.al Actuating sangat berbeda dengan ketiga fungsi lain (planning, organizing, controlling), actuating merupakan intisari manajemen karena secara khusus berhubungan dengan orang-orang, bagaimana seorang pemimpin menggerakkan bawahanya agar mau bekerja dan melaksanakan tugasnya. Tercapai tidaknya tujuan/visi-misi lembaga dan berjalanya roda organisasi tergantung dari bagaimana fungsi penggerakan ini berjalan dengan maksimal.

\section{d. Pengawasan (controlling)}

Pengawasan adalah pengukuran dan koreksi pencapaian tujuan untuk meyakinkan bahwa semua kegiatan sesuai dengan rencana. Pengawasan merupakan sebuah proses aktifitas pengawasan serta pengukuran suatu kegiatan operasional dan hasil akhir dengan standar yang telah ditentukan. Proses pengawasan dilakukan dalam rangka menjamin dan memastikan bahwa seluruh rangkaian kegiatan terlaksana sesuai dengan kebijakan, strategi, keputusan, rencana dan program kerja yang telah dianalisis, dirumuskan dan ditetapkan sebelumnya. (Hidayat and Machali 2012:25-26).

Fungsi dari pelaksanaan pengawasan adalah sebagai tolo ukur tingkat efektifitas kinerja personal ataupun kelompok organisasi serta tingkat efisiensi penggunaan instrument pendukung dalam usaha mencapai tujuan organisasi. Dalam prosesnya, pegawasan memerlukan langkah-langkah diantaranya; a) 
menentukan tujuan standar kualitas pekerjaan yang diharapkan baik berupa fisik, biaya, model, penghasiln, program serta tujuan yang realistis, b) mengukur dan menilai kegiatan-kegiatan atas dasar tujuan dan standar yang ditetapkan, c) memutuskan dan mengadakan tindakan perbaikan.

\section{Pendidikan Islam Non Formal}

Sebagai salah satu bagian dari Sistem Pendidikan nasional tentunya lembaga pendidikan Islam tersebut tidak terlepas dari tujuan. Sebagaimana Ahmad Tafsir menuturkan pendidikan di dalam Islam, adalah sebagai bimbingan yang diberikan oleh seseorang agar ia berkembang secara maksimal sesuai dengan ajaran Islam(Tafsir 2010:28-32). Hal tersebut selaras dengan heirarki kelembagaan pendidikan non formal tersebut yang berada dibawah payung takmir masjid Al Hidayah sehingga jelas sebagai bagian dari pengembangan pendidikan Islam.

Pada perjalananya masing-masing lembaga tersebut lahir dan berdiri seiring perkembangan dan antusiasme masyarakat terhadap kebutuhan akan pendidikan anak usia dini. Pendidikan nonformal merupakan perwujudan dari demokratisasi pendidikan melalui perluasan pelayanan pendidikan untuk kepentingan masyarakat. Pendidikan ini menjadi sebuah gerakan penyadaran masyarakat untuk terus belajar sepanjang hayat dalam mengatasi tantangan kehidupan yang berubah-ubah dan semakin berat (Rahmawati 2014).

Menurut Marimba, Pendidikan adalah bimbingan dan pimpinan secara sadar oleh pendidik terhadap perkembangan jasmani dan rohani anak menuju terbentuknya kepribadian yang utama(Marimba 1989:19). Park menjelaskan pendidikan dalam arti yang lebih sempit dengan istilah pengajaran. Ia mengatakan bahwa pendidikan adalah the art of importing or acquiring knowladge and habit throught instructional as study (Park 1962:3). Sebagaimana kajian pendidikan dalam hal ini adalah Islam, oleh Ahmad Tafsir menjelaskan kata Islam dalam pendidikan Islam menunjukkan warna pendidikan tertentu, yaitu pendidikan yang berwarna Islam (Tafsir 2014:24). Pendidikan Islam diartikan sebagai pendidikan yang didasari dengan nilai-nilai ajaran Islam yaitu Al Qur'an dan Al Hadist. Menurut Omar Muhammad Al Toumy Al Syaebani memberikan penjelasan tentang pendidikan Islam "sebagai proses mengubah tingkah laku individu dalam kehidupan pribadinya atau kehidupan kemasyarakatannya dan alam sekitarnya 
melalui interaksi yang dilakukan oleh individu tersebut"(Syaibany 1979:57).

Menurut beberapa tokoh yang mendefinisikan Pendidikan Islam, pertama, menurut Ahmadi bahwa Pendidikan Islam adalah segala usaha untuk memelihara fitrah manusia serta sumber daya insani yang ada padanya menuju terbentuknya manusia seutuhnya (insan kamil) yang sesuai dengan norma Islam. Kedua, menurut Syekh Musthafa Al-Ghulayani memaknai pendidikan adalah menanamkan akhlak mulia dalam jiwa murid serta menyiraminya dengan petunjuk dan nasehat, sehingga menjadi kecenderungan jiwa yang membuahkan keutamaan kebaikan serta cinta belajar yang berguna bagi tanah air. Khusus berkaitan dengan pendidikan anak usia dini merupakan program pendidikan yang diarahkan pada upaya pembelajaran yang sesuaidengan tingkat usia anak dalam kemampuannya menggali potensi, sehingga anak memiliki bekal untuk perananya memasuki kehidupannya di masa depan (Nugroho 2015:282).

Mencermati masing-masing definisi muncul sisi kesamaan pada aspek tujuannya, sehingga Isma'il memberikan sebuah gambaran tentang tujuan pendidikan Islam yaitu membimbing anak didik dalam perkembangan dirinya, baik jasmani maupun rohani menuju terbentuknya kepribadian yang utama pada anak didik nantinya yang didasarkan pada hukum-hukum Islam (Isma'il 2008:3436).

Tujuan pendidikan Islam bertumpu pada terealisasinya ketundukan kepada Allah SWT baik dalam level individu, komunitas dan manusia secara luas. Mewujudkan tujuan pendidikan, diperlukan adanya kesinambungan antara komponen-komponen pendidikan Islam. Selain tujuan, komponen lainnya seperti metode, media, kurikulum, evaluasi, guru, dan murid juga sangat menentukan keberhasilan dari pendidikan Islam itu sendiri. Karena pendidikan merupakan sebuah sistem dan sebuah sistem tidak dapat berjalan dengan baik jika salah satu komponennya bermasalah sehingga komponen satu dengan komponen lainnya sangat mempengaruhi(Huda 2015:5).

Menurut Coombs, pendidikan nonformal adalah setiap kegiatan yang diorganisasikan di luar sistem persekolahan yang mapan apakah dilakukan secara terpisah atau seagian bagian penting dari kegiatan yang lebih luas, dilakukan secara sengaja untuk melayani anak didik tertentu untuk mencapai tujuan belajarnya.(Rahmat 2017:4) 
Evans (1981) menggolongkan pendidikan nonformal ke dalam klasifikasi: (a) pendidikan pelengkap yang saling melengkapi dengan kurikulum sekolah, (b) pendidikan penambah yang menambahi kekurangan pendidikan sekolah pada tempat dan waktu yang berlainan, (c) pendidikan pengganti yang menggantikan sama sekali pendidikan sekolah, dan (d) proses pendidikan terintegrasi yang tersedia sepanjang hayat.(Suryono and Tohani 2016:19-20)

\section{Bentuk Lembaga Pendidikan Islam Non Formal Al Hidayah}

Kata lembaga dalam Kamus Besar Bahasa Indonesia adalah badan(organisasi) yang tujuannya melakukan suatu penyelidikan keilmuan atau melakukan usaha.(Tim Penyusun 1999:579-580) Sedangkan lembaga pendidikan Islam adalah lembaga atau tempat yang berarti lokasi dimana proses pendidikan islam berlangsung. Lembaga pendidikan islam adalah tempat berlangsungnya proses pendidikan yang dilakukan dengan tujuan untuk mengubah tingkah laku individu kearah yang lebih baik melalui interaksi dengan lingkungan sekitarnya. Dan perubahan yang dimaksud tentu dilandasi dengan nilai-nilai Islami.(Hawi 2017:144)

Sebagaimana dijelaskan dalam Undang-Undang No.20 Tahun 2003 Pasal 26, pemerintah telah memberi batasan terkait apa yang dimaksud dengan pendidikan non formal. Dalam UU tersebut ditegaskan bawa satuan pendidikan non formal terdiri atas lembaga kursus, lembaga pelatihan, kelompok belajar, pusat kegiatan belajar masyarakat, dan majelis taklim serta satuan pendidikan sejenis (SPS).(UU Sisdiknas RI 2003) Sedangkan untuk Pendidikan diniyah bisa diselenggarakan secara formal, nonformal dan informal.(UU Sisdiknas RI 2003:Khususnya pasal 1 ayat 11,12, dan 13, dikenal tiga jalur pendidikan; formal, nonformal dan informal. Pendidikan formal adalah jalur pendidikan yang terstruktur dan berjenjang yang terdiri atas pendidikan dasar, pendidikan menengah, pendidikan tinggi. Pendidikan nonformal adalah jalur pendidikan di luar pendidikan formal yang dapat dilaksanakan secara terstruktur dan berjenjang. Sedangkan pendidikan informal merupakan jalur pendidikan keluarga dan lingkungan.) Beberapa perbedaan lembaga pendidikan Diniyah lainya dijelaskan oleh Kosim dalam jurnalnya sebagai berikut: 
Tabel 1.

Pengklasifikasian Pendidikan Diniyah (Kosim 2009:240).

\begin{tabular}{|c|c|c|}
\hline No & Jenis & Keterangan \\
\hline \multirow[t]{5}{*}{1} & Formal & Diniyah Athfal \\
\hline & & Diniyah Ula \\
\hline & & Diniyah Hustha \\
\hline & & Diniyah Ulya \\
\hline & & Diniyah 'Aly \\
\hline \multirow[t]{5}{*}{2} & Non-Formal Berjenjang & Diniyah Takmiliyah Awwaliyah \\
\hline & & Diniyah Takmiliyah \\
\hline & & Wustha \\
\hline & & Diniyah Takmiliyah Ulya \\
\hline & & Diniyah Takmiliyah 'Aly \\
\hline \multirow[t]{4}{*}{3} & Non Formal tak & Pengajian Kitab \\
\hline & Berjenjang & Majelis Taklim \\
\hline & & Taman Pendidikan Al Qur'an \\
\hline & & Bentuk-bentuk lain yang sejenis \\
\hline 4 & In Formal & Keluarga dan Lingkunga \\
\hline
\end{tabular}

Proses pendidikan tidak bisa lepas dari lembaga pendidikan yang tergabung dalam istilah Tripusat Pendidikan yang meliputi keluarga, sekolah dan masyarakat. Munculnya berbagai masalah dan problematika yang terjadi di lingkungan pendidikan keluarga dan sekolah menjadi dasar yang menyebabkan pendidikan nonformal mengambil peran untuk membantu pendidikan keluarga dan sekolah mengatasi problematika tersebut.

Dalam Undang-Undang RI No. 20 Tahun 2003 tentang Sistem Pendidikan Nasional Pasal 26 ayat 1 menyebutkan Pendidikan nonformal diselenggarakan bagi warga masyarakat yang memerlukan layanan pendidikan yang berfungsi sebagai pengganti, penambah, dan/atau pelengkap pendidik formal dalam rangka mendukung pendidikan sepanjang hayat.(UU Sisdiknas RI 2003) 
Lembaga Pendidikan Nonformal Al Hidayah memiliki tiga unit kelembagaan yang ketiga-tiganya dikelola secara bersama sama bersifat integral tidak terpisahkan dalam satu atap dibawah manajemen ketakmiran masjid $\mathrm{Al}$ Hidayah. Ketiga unit kelembagaan tersebut ialah:

a. Pendidikan Anak Usia Dini Berbasis Al Qur'an/ PAUD-TPQ Al Hidayah (Umur 2- 6 tahun)

b. Taman Pendidikan al-Qur'an Al Hidayah (umur 6-12 tahun)

c. Madrasah Diniyah Takmiliyah Hidayatut Tholibin (umur 12-15 tahun)

Ketiga lembaga pendidikan diatas memiliki struktur organisasi yang menyatu/terintegrasi serta dalam pelaksanaanya berjalan integral saling melengkapi dan menguatkan satu dan lainya. Dalam pelaksanaannya KBM, PAUD TPQ tersebut dilaksanakan dengan konsep TPQ yaitu pada waktu sore hari mulai jam 15.30-17.15 setiap hari Senin sampai dengan Kamis. Dengan kegiatan ekstra setiap hari Ahad pagi, begitu pula pada pelaksanaan KBM Madin dan TPQ sendiri. Dikarenakan terselenggara secara integral maka manajemennya menyatu dalam satu komando pengasuh Pendidikan Islam Al Hidayah, meskipun demikian masing-masing lembaga juga dilengkapi oleh kepala dan guru pengampu masingmasing.

6. Pelaksanaan Manajemen LPI Nonformal Al Hidayah Juranggunting Salatiga.

Pada aspek manajerial yang paling utama adalah langkah planning, organizing, Actuating, dan Controlling. Meskipun dalam aspek actuating beberapa tokoh manajemen membahasakan dengan istilah-istilah yang bervariasi meskipun dalam maknanya memiiki kesamaan satu dengan lainya.Tanpa keempat langkah manajemen tatakelola tersebut niscaya lembaga bisa dipastikan akan stagnan dalam pengelolaanya dan tidak bisa berjalan dengan maksimal. Perjalanan lembaga pendidikan Islam non formal "satu atap" Al Hidayah ini telah berjalan bertahun-tahun dan bahkan beberapa ustadz-ustadzah adalah bagian dari alumni yang dulunya juga belajar dan menjadi santri dari lembaga tersebut. Sistem regenerasi pengajar menjadi faktor utama pendukung perkembangan kelembagaan mengingat para pengajar di lembaga ini dari internal pemuda dan murni bentuk pengabdian. Regenerasi tersebut dilakukan dengan beberapa pertimbangan diantaranya; pengajar telah menikah, pindah domisili, repot dengan aktifitas 
keluarga atau berkerier yang tidak bisa ditinggalkan sehingga mengharuskan berhenti dari kepengurusan serta aktifitas pengabdian sebagai pendidik di lembaga al-Hidayah.

Pada kajian ini fokus bahasan pengelolaan manajemen lembaga melingkupi empat aspek mulai dari perencanaan, pengorganisasian, penggerakan dan pengawasan. Pada tahap selanjutnya peneliti perlu menyampaikan paparan data lapangan yang berjalan selama ini kaitanya dengan tatakelola kelembagaan sebagai berikut:

\section{a. Planning/ perencanaan}

Dalam perjalananya kaitanya dengan perencanaan, system desentralisasi lebih mendominasi. Dalam artian jajaran takmir memberikan kewenangan kepada pengasuh untuk membentuk dan mengatur dan merencanakan jalanya lembaga pendidikan sebaik mungkin. Para pendidik didominasi oleh para remaja masjid yang aktif tidak hanya sebagai pengajar di tiga lembaga tersebut tetapi juga memiliki kesibukan dan aktifitas diluar lembaga atau kampung.

Dalam pelaksanaan perencanaan dari ketiga lembaga tersebut sudah dilaksanakan dengan baik mengingat munculnya masing-masing lembaga direncanakan sebagai jawaban dan jembatan bagi kegiatan pendidikan non formal bagi anak-anak dilingkungan dukuh juranggunting dan sekitarnya. Dari hasil wawancara dan observasi dengan beberapa pengurus didapatkan perencanaan yang sudah dibuat oleh pengurus dari ketiga jenjang lembaga tersebut diantaranya((WFS) Inisial 2018):

1) Merencanakan penyusunan tujuan akhir dari masing-masing jenjang lembaga dalam istilah lain visi dan misi dan tujuan.

2) Membuat rencana kegiatan pembelajaran yang terprogram baik pada jenjang PAUD-TPQ, TPQ maupun Madin melalui pemenuhan kurikulum yang sifatnya berupa sebaran mata pelajaran beserta daftar pengampu mata pelajarannya.

3) Merancang berbagai kegiatan penunjang pembelajaran baik jenjang PAUD-TPQ, TPQ serta Madrasah diniyah yang bersifat akademik maupun ekstrakulikuler. Beberapa rencana kegiatan ekstrakurikuler ada yang bersifat rutin dan ada yang bersifat insidental. Diantara kegiatan kegiatan tersebut seperti kegiatan ziarah bersama, kegiatan sholawatan atau berzanji 
di masjid bersama, kegiatan outbond bersama, kegiatan akhirusannah pada akhir tahun pelajaran, kegiatan pentas seni kreasi, kegiatan olah raga bersama, kegiatan atau ivent-ivent perlombaan.

4) Membuat beberapa kegiatan pertemuan rutin antar pengurus dan pertemuan rutin bersama dengan wali murid/wali santri dan pertemuan bersama dengan para perangkat ketakmiran dan pimpinan masyarakat dan tokoh masyarakat, khususnya menjelang akhir tahun pembelajaran dan pelaksanaan HaflahAkhirussanah.

5) Membuat perencanaan penjenjangan kelas sesuai dengan usia santri dan kemampuan pretest.

6) Mendata daftar kebutuhan sarana dan prasarana penunjang kegiatan

7) Membangun jejaring dengan stakeholder yang kedepanya akan dijadikan sebagai donatur tetap guna menunjang pembiayaan kelembagaan, Bisyaroh para pendidik dan biaya operasional lainya.

8) Membangun susunan kepengurusan yang akan menjalankan segala aktiitas dan kegiatan kelembagaan baik pada tingkat PAUD-TPQ, TPQ dan Madin.

9) Membagi beban kerja mulai dari jadwal mengajar, beban tanggung jawab kelembagaan seperti kepala lembaga, sekretaris lembaga, Bendahara lembaga, pengelola kurikulum, pengelola data kesiswaan/kesantrian, pengelola sarana dan prasarana dan lain sebagainya

10) Membuat jadwal agenda tes akhir tahun dan penutupan akhir pembelajaran Agenda rencana tersebut disusun bersama-sama dengan mempertimbangkan segi kelengkapan sarana dan prasarana yang ada. Dari hasil observasi lapangan didapatkan bahwa lembaga pendidikan non-Formal Al Hidayah tersebut terselenggara dengan menggunakan lima gedung utama memanfaatkan ruangan masjid dan aula. Terdapat dua masjid sebagai pusat pembelajaran yaitu masjid Al-Hidayah dan masjid Baiturrahman yang keduanya berada di wilayah RT 1 Juranggunting. Para pengurus membagi ruangan kelas dengan mempertimbangkan segala aspeknya termasuk ketersediaan tidaknya ruangan kelas menjadi rencana jangka panjang yang difikirkan dan hendak dicapai. Sementara ini pengelola mengoptimalkan ruangan yang sudah ada yaitu tiga ruang utama yang terdiri dari satu ruang 
kelas PAUD-TPQ, satu ruangan Aula serbaguna di kompleks masjid Baiturrahman yang digunakan sebagai kelas TPQ awal dan satu ruangan aula serbaguna di Masjid Al Hidayah yang digunakan sebagai kelas Madrasah Diniyah. Selain ruang utama tersebut, pengelola memanfaatkan serambi masjid baik luar maupun dalam untuk dijadikan sebagai kelas atau ruangan pembelajaran.

\section{b. Organizing/Pengorganisasian}

Pembahasan terkait pelaksanaan manajemen kelembagaan lembaga pendidikan non formal al hidayah tidak bisa dilepaskan dari struktur keorganisasian lembaga dari masing-masing jenjang lembaga. Pada aspek manajemen pengorganisasian, ketiga lembaga ini telah dijalankan sistem organizing, hal tersebut terlihat manakala peneliti mencoba menemui pengasuh dan mengarahkan kepada beberapa pengurus yang membidangi aspek-aspek tertentu seperti kepala lembaga, kurikulum, bendahara, kesiswaan, pengelola sarana prasarana dan ustadz-ustadzah. Peran pengasuh hanya sebatan memberikan arahan dan keputusan akhir, selebihnya yang menjalankan adalah masing-masing kepala dan sekretaris yang mengatur jalanya program secara keseluruhan. Lembaga pendidikan ini terbagi menjadi tiga mulai dari PAUDTPQ Al Hidayah yang masuk dalam satuan PAUD sejenis (SPS), Taman Pendidikan Al Qur'an (TPQ) dan Madrasah Diniyah (MADIN).

Struktur keorganisasian lembaga terdiri dari Pengasuh lembaga pendidikan yang bertanggung jawab terhadap takmir masjid, sekretaris lembaga yang bertugas mengatur jalanya organisasi, menyusun data administrasi dan segala kelengkapannya termasuk dalam hal ini kurikulum, bendahara yang bertugas mengatur keluar masuknya dana lembaga, kepala lembaga yang bertugas memastikan masing-masing lembaga berjalan dengan baik dan maksimal dan ustadz-ustadzah atau guru yang bertugas mengajar dan melaksanakan kegiatan-kegiatan yang telah diprogramkan bersama. Ketiga lembaga tersebut dilaksanakan oleh 12 personil secara terintegrasi.

\section{c. Actuating/penggerakan}

Berbicara tentang penggerakan organisasi, dari hasil wawancara terhadap pengurus didapatkan data bahwa pengelolaan organisasi kelembagaan mengalami kemunduran dari tahun ke tahun. Hal ini dikarenakan pergantian 
personil atau pengurus yang disebabkan oleh beberapa hal seperti menikah, pindah domisili, beban pekerjaan serta hal-hal lain yang membuat kepengurusan menjadi kurang stabil. Kurangnya motivasi pendorong seperti tidak adanya biysaroh tiap bulanya juga berdampak pada melemahnya loyalitas pengurus terhadap tanggung jawab. Aktifitas penggerakan yang dijalankan hanya sebatas semampunya. Motivasi yang terlihat dilakukan oleh jajaran ketakmiran yang sudah berjalan selama ini adalah pemberian reward atau tali asih kepada para pegurus setiap satu tahun sekali menjelang idul fitri.

Kegiatan actuating dilakukan langsung oleh pengasuh dengan memberikan komando kepada sekretaris untuk menjalankan roda organisasi. Berbagai program kegiatan selanjutnya sekretaris yang menjalankan mulai dari membuat visi dan misi, menyusun jadwal, membagi kelas dan lain sebagainya dan selanjutnya oleh sekretaris membuat agenda pertemuan dengan para pengurus untuk bersama-sama membahasnya.

Menurut hasil wawancara didapatkan selama ini belum ada pembagian job yang jelas terkait pengelolaan kelembagaan, kesemuanya murni dihandel langsung oleh sekretaris yang berkoordinasi langsung kepada pengasuh. Masing-masing personil menjalankan program sesuai inisiatifnya sendiri tanpa berkoordinasi dengan pengasuh atau rapat bersama seperti contoh kegiatan al barzanji dan pergeseran waktu pelaksanaanya. Tidak adanya kejelasan pemimpin lembaga menjadikan perencanaan sukar dilaksanakan, oleh siapa dan kapan. Hal ini dikuatkan dengan pemaparan dalam wawancara “...menurut saya selama ini terkesan belum dikelola dengan maksimal, Perlu disusun pembagian Job description/pekerjaan yang jelas dan sesuai dengan kompetensi. Bukan semuanya terbebankan pada satu orang...”((HR) Inisial 2018)

Dalam proses pembelajaranya, meskipun oleh sekretaris lembaga telah diatur terkait jadwal mengajar sebagaimana kurikulum yang syarat akan kemudahan, akan tetapi didapatkan masih ada ustadz/ustadzah pada waktu jadwal mengajarnya masih ditemukan kelas yang kosong. Menurut pemaparan pengasuh hal ini dikarenakan kurangnya keistiqomahan dan keikhlasan dalam mengabdi. 


\section{d. Controling /Pengawasan}

Pengawasan atau controlling dalam proses pelaksanaan pengelolaan lembaga merupakan salah satu fungsi yang sangat penting dalam rangka mencapai hasil implementasi manajemen organisasi yang berkaitan dengan proses maupun keberadaan sumber daya yang ada. Pengawasan sangat erat kaitanya dengan perencanaan strategis. Dan perencanaan strategis merupakan langkah paling utama dalam proses manajemen yang dilakukan untuk merumuskan tujuan yang akan dicapai organisasi dan juga merencanakan berbagai sumber daya yang ditetapkan organisasi dan usaha pencapaian tujuan strategis. Pengawasan biasanya dilakukan oleh seorang yang memiliki otoritas tinggi terhadap bawahanya.

Berkaitan dengan proses pengawasan yang terlaksana di lembaga pendidikan Islam al -Hidayah selama ini memang belum terlihat maksimal, hanya dalam beberapa kasus yang terjadi hal tersebut menjadi sebuah bentuk pengawasan yang telah berjalan. Pengawasan bisa melalui pengurus takmir masjid sebagai lembaga yang bertanggung jawab penuh terhadap keberadaan kelembagaan, pengasuh lembaga serta masyarakat. Masyarakat dalam hal ini meliputi tokoh masyarakat, masyarakat lingkungan lembaga serta wali santri.

Adapun tindak lanjut dari bentuk-bentuk pengawasan tersebut belum sepenuhnya dilaksanakan. Justru dari bentuk pelaksanaan yang terjadi menjadikan pengurus semakin kurang bersemangat mengingat kontribusi dan tanggung jawab pengurus terhadap keberadaan lembaga sangat besar, akan tetapi imbal balik yang didapatkan justru hal yang tidak menyenangkan karena pengurus kurang memiliki bergaining.

\section{Faktor pendukung dan penghambat manajemen lembaga}

Perkembangan serta perjalanan lembaga pendidikan Islam non formal satu atap Al-Hidayah ini tidak lepas baik dari faktor pendukung maupun faktor penghambat. Diantara kedua faktor tersebut sebagai berikut:

a. Faktor Pendukung

Berbicara tentang faktor pendukung keberhasilan sebuah pengelolaan kelembagaan akan selalu berkaitan erat dengan dua faktor yaitu internal dan eksternal. Menurut hasil observasi lapangan yang dilakukan oleh peneliti terhadap proses pengelolaan lembaga pendidikan non formal satu atap ini 
didapati faktor internal pendukung keberhasilan pengelolaan diantaranya: 1) sarana prasarana yang memadahi, 2) pengelola yang memiliki kualifikasi sebagai pendidik dan kompetensi keagamaan lulusan pesantren dan sarjana, 3) Rasa pengabdian yang tinggi terhadap lembaga membuat para pengurus tetap bertahan ikut mengelola dan mengajar di lembaga pendidikan Al Hidayah.

Adapun beberapa faktor eksternal yang mendukung berjalanya lembaga diantaranya, 1) perangkat masyarakat dalam hal ini ketua RW dan RT yang mendukung progam pendidikan baik melalui relasi pejabat pemerintahan ataupun melalui forum-forum masyarakat. 2) dukungan masyarakat dan pengurus takmir masjid terhadap lembaga tampak dengan keikutsertaanya dalam mendukung dan mensukseskan acara-acara insidental seperti moment wisuda atau akhirusanah serta pembangunan gedung.

b. Faktor penghambat

Menurut pengamatan peneliti melihat keberlangsungan manajemen ketiga lembaga tersebut sangat tergantung dari figur salah satu penggerak dalam hal ini sekretaris yang diamanahi pengasuh untuk merumuskan segala bentuk perencanaan kegiatan. Pengasuh lembaga memberikan kewenangan kepada pengurus lain yang diberikan amanah menggerakkan organisasi, peran pengasuh menjadi rujukan utama untuk dimintai pertimbangan terkait hal-hal penting dan kegiatan kegiatan yang berhubungan dengan kelembagaan. Hal tersebut terbukti manakala terjadi pergantian kepengurusan oleh salah satu pengelola atau beberapa pengelola membuat proses pelaksanaan baik kegiatan pembelajaran maupun pengelolaan manajemen menjadi terkendala. Peneliti amati dari hasil observasi dan wawancara kepada beberapa pengurus, setiap terjadi reorganisasi kepengurusan bisa dipastikan terjadi warna yang berbeda baik yang bersifat meningkat ataupun sebaliknya bisa bersifat menurun.

Faktor penghambat lainya apabila berbicara tentang kompetensi pengurus, kepengurusan ketiga lembaga ini bisa dikatakan sangat berkualitas karena dibeck-up oleh para remaja masjid yang memiliki kompetensi sarjana dan alumni pesantren. Akan tetapi problematika lainya adalah melemahnya semangat motivasi dan keistiqomahan dalam berkhidmad. Hal tersebut dikuatkan oleh pemaparan pengasuh lembaga bahwa kendala utama 
pengelolaan lembaga bukan sekedar minimnya skil pengelola, melainkan kurangnya keistiqomahan dari para pengurus.((MAR) Inisial 2018)

Selain itu MAR menambahkan bahwa kendala yang muncul juga diakibatkan dari faktor eksternal lembaga diantaranya karena pengelelola lembaga didominasi oleh kalangan pemuda yang kurang memiliki bergaining sehingga terkesan kalah power ketika menghadapi masyarakat ketika muncul control dan pengawasan yang terlalu tajam.

Penurunan kualitas tersebut menurut pengamatan penulis ketika bertemu dengan pengasuh, sekretaris serta bendahara dan para pengurus lainya terlihat belum ada usaha dari penanggung jawab lembaga untuk memberikan dorongan motivasi baik berupa moril maupun materiil seperti bisyaroh atau honorarium tiap bulan. Motivasi berupa honorarium yang ada hanyalah bersifat untuk tali asih diberikan setahun sekali menjelang hari raya idul fitri. Hal ini salah satunya membawa dampak pada melemahnya semangat dan motivasi dan loyalitas dalam mengabdi di lembaga hal ini dikuatkan oleh pernyataan sekretaris lembaga merasakan begitu sulitnya membuat sebuah keputusan berkaitan dengan manajemen tatakelola lembaga karena ini lembaga non-profit.((WFS) Inisial 2018)

Selain itu, menurunya peran orang tua dalam memotivasi anak, lemahnya manajemen pengelolaan masjid yang berefek terhadap pengelolaan lembaga pendidikan al-Hidayah, lemahnya penggerakan /actuating lembaga, perhatian dari sesepuh/pimpinan terhadap motivasi para SDM kurang maksimal yang bersifat moril (motivasi) maupun materil (bisyaroh), minimnya moment pertemuan pengurus, pertemuan dengan stakeholder dan pertemuan walisantri.

\section{Langkah pengembangan manajemen lembaga pendidikan Islam Nonformal}

Beberapa langkah atau usaha yang telah dan akan dilakukan dalam rangka pengembangan kelembagaan pendidikan al Hidayah diantaranya adalah melakukan regenerasi sekaligus restrukturisasi kepengurusan. Hal ini dikarenakan semakin banyak personil yang mulai beralih karena keadaan seperti personil menikah dan pindah domisili, mulai muncul kerepotan seperti anak dan lainsebagainya mengingat pengurus berada di al hidayah hanya sebagai 
pengabdian sehingga sangat mudah sekali untuk meninggalkan tugas maupun tanggung jawab.

Dari paparan data pada bab awal didapatkan juga perlunya restrukturisasi kepengurusan. Pembagian job describtion yang jelas dan penataan adminstrasi kelembagaan dari berbagai aspek. Beban pekerjaan administrasi dari ketiga lembaga yang ada tidak mungkin hanya terbebankan pada salah seorang personil. Pada posisi ini perlunya menggerakkan organisasi untuk berbagi peran dan berbagi pekerjaan meskipun kaitanya dengan status pengurus sebatas sebuah pegabdian. Perlunya mereview kembali visi-misi dan tujuan lembaga guna menyusun dan mengembangkan kurikulum untuk tiap jenjangnya. Selain itu terkait dengan dana, perlunya pengurus untuk melakukan sosialisasi, penjaringan dan pendataan terkait donatur tetap guna mendukung pembiayaan operasional kelembagaan. Mengkomunikasikan dengan pihak ketakmiran sebagai penanggung jawab segala operasional lembaga untuk mau ikut memikirkan bersama sama bagaimana meningkatkan kesejahteraan pengurus sekaligus pengajar. Melibatkan pengurus dalam setiap aktifitas kegiatan ketakmiran seperti rapat bersama dan sejenisnya. Dengan demikian motivasi pengabdian para pengurus akan meningkat dan dipastikan mampu meningkatkan pula kualitas pengelolaan kelembagaan.

\section{Simpulan}

Beberapa hal yang telah dilakukan para pengurus dan pengelola Lembaga Pendidikan Islam Non Formal al-Hidayah guna keberhasilan dan ketercapaian lembaga diantaranya adalah perlunya penguatan manajemen. Pepatah arab mengatakan "kebaikan yang tidak terorganisir akan dikalahkan oleh kejahatan yang terorganisir". Dalam rangka mengejawantahkan pepatah diatas maka perlunya seluruh elemen pendidikan al Hidayah harus sadar mutu, sadar administrasi.

Khususnya berkaitan dengan bidang manajemen pendidikan Islam Non formal al hidayah terkait dengan pelaksanaan manajemen lembaga di al-Hidayah dilaksanakan dengan menggunakan system pengelolaan "Satu Atap". Ketiga lembaga dikelola dengan kepengurusan tunggal dan bertumpu pada pengelola yang dibantu oleh salah seorang individu dalam hal ini sekretaris dan seorng bendahara. Para kepala lembaga sebagai koordinator kelas dan menghandel kelas ketia ditemukan kendala kekosongan pengajar. Terkait dengan empat fungsi manajemen baik perencanaan, pengorganisasian, penggerakan dan pengawasan belum sepenuhnya berjalan 
maksimal. Beberapa kendala muncul diantaranya melemahnya loyalitas kepengurusan, hilangnya motivasi dalam mengelola dan mengajar, kurangnya motivasi dari pimpinan dan penanggung jawab lembaga.

Adapun beberapa langkah usaha yang perlu diakukan diantaranya; a) Melakukan tata kelola ulang struktur organisir yang baik. Organisasi lembaga bisa dikatakan dengan Manajemen, b) menghidupkan fungsi-fungsi manajemen yaitu mulai dari perencanaan, pengorganisasian, pelaksanaan dan pengawasan yang dilakukan oleh pengelola dan dibantu oleh sekretaris, Bendahara dan unit- unit lainnya sebagai pelaksananya, c) Menjalin kerjasama kembali dan komunikasi intens dengan pihak takmir agar jajaran takmir mau ikut memikirkan kesejahteraan pengurus tiap bulanya, d) Restrukturisasi dan menyusun strategi perekrutan kepengurusan baru mengingat banyaknya personil yang mulai melemah dikarenakan faktor keluarga ataupun pekerjaan utama dan domisili, e) Menyusun rencana strategis jangka pendek menengah dan jangka pajang serta langkah implementasinya. Dalam hal ini pembagian job describtion harus diperjelas agar masing-masing personil memiliki tanggungjawab dan raa memiliki terhadap lembaga, f) Kegiatan yang selama ini telah berjalan baik perlu dipertahankan sekaligus menyusun rencana tindaklanjut pengembangan manajemen kelembagaan. Melengkapi kepengurusan yang sekiranya penting seperti petugas jaga /piket.g) Melaksanakan pertemuan rutin dan musyawarah bersama pengurus yang melibatkan stakeholder. 


\section{DAFTAR PUSTAKA}

Burhanuddin, 1994, Analisa Administrasi Manajemen Dan Kepemimpinan Pendidikan. Bandung: Mizan.

Damopolii, Mujahid, 2015 Problematika Pendidikan Islam Dan Upaya-Upaya Pemecahannya,. TADBIR Jurnal Manajemen Pendidikan Islam, IAIN Sultan Amai Gorontalo Volume 3(No 1): 68-81.

Direktorat Pembinaan Pendidikan Anak Usia Dini-Direktorat Jenderal Pendidikan Anak Usia Dini, Non Formal dan Informal 2011 Petunjuk Teknis Penyelenggaraan PAUD Berbasis Taman Pendidikan Al Qur'an (PAUD-TPQ). Kementerian Pendidikan Nasional.

Donnelly. JR., James H. 1981. Fundamentals of Management. Irwin Dorsey: Business Publications.

Fatah, Nanang, 2012 Standar Pembiayaan Pendidikan. Bandung: PT Remaja Rosdakarya.

(FR) Inisial 2018, Wawancara. July 21.

Hawi, Akmal, 2017 Tantangan Lembaga Pendidikan Islam. Tadrib: Jurnal Pendidikan Agama Islam 3(1): 143-161.

Hidayat, Ara, and Imam Machali, 2012,Pengelolaan Pendidikan [Konsep, Prinsip, Dan Aplikasi Dalam Mengelola Sekolah Dan Madrasah]. Yogyakarta: Penerbit Kaukaba.

(HR) Inisial, 2018, Wawancara. July 21.

Huda, Miftahul. 2015 Peran Pendidikan Terhadap Perubahan Sosial. Edukasia: Jurnal Penelitian Pendidikan Islam Vol. 10,(No. 1): 165-188.

Irawan, Prasetya. 1997.Manajemen Sumber Daya Manusia. Jakarta: STIA-LAN Press.

Isma'il. 2008 Strategi Pembelajaran Islam Berbasis PAIKEM (Pembelajaran Aktif, Inovatif, Kreatif, Efektif, Dan Menyenangkan). Semarang: Rasail.

Kadir, M. Sardjan. 1982. Rencana Pendidikan Non Formal. Surabaya: Usaha Nasional.

Kosim, Mohammad. 2009. Langgar Sebagai Institusi Pendidikan Keagamaan Islam. TADRIS: Jurnal Pendidikan Islam 4(2).

Kristiawan, Muhammad, Dian Safitri, and Rena Lestari. 2017. Manajemen Pendidikan. Yogyakarta: Deepublish.

(MAR) Inisial. 2018 Wawancara. June 10.

Marimba, Ahmad D. 1989. Pengantar Filsafat Pendidikan Islam. Bandung: Al-Maarif. 
Miles, M.B \& Huberman, A.M.1992 .Analisis Data Kualitatif: Penerjemah Tjetjep Rohendi R. Universitas Indonesia Press.

Moleong, Lexy J. 2002. Metodologi Penelitian Kualitatif. Bandung: Remaja Rosdakarya.

Nana Syaodih, Sukmadinata. 2008. Metode Penelitian Pendidikan. Bandung: PT Remaja Rosda Karya.

Nasional, Sistem Pendidikan. 2003. Undang-Undang Republik Indonesia Nomor 20 Tahun 2003. Jakarta, Depertemen Pendidikan Nasional Republik Indonesia.

Nugroho, Puspo. 2015. Pandangan Kognitifisme Dan Aplikasinya Dalam Pembelajaran Pendidikan Agama Islam Anak .

Park, Joe. 1962. Selected Reading in the Philosophy of Education. New York: The Macmillan Company.

Peraturan Menteri Agama Republik Indonesia No 13 Tahun 2014 Tentang Pendidikan Keagamaan Islam. N.d.

Rachman, Fathor. 2015. Manajemen Organisasi dan Pengorganisasian dalam Perspektif AL-Qur'an dan Hadith. Ulûmunâ : Jurnal Studi Keislaman Vol. 1(No. 2).

Rahmat, Abdul. 2017. Manajemen Pendidikan Nonformal. Jawa Timur: Penerbit Wade.

Rahmawati, Ika. 2014. Pendidikan Islam Non Formal Bagi Masyarakat Pinggiran Di Majelis Asy-Syifa Gilingan Kecamatan Banjarsari Surakarta Tahun 2013-2014. Naskah Publikasi Skripsi, Universitas Muhammadiyah Surakarta.

Riyanto, Yatim. 2007.Metodologi Penelitian Pendekatan Kualitatif. Surabaya: Unesa University Press.

(SNA) Inisial. 2018. Wawancara. June 12.

Sugiono. 2009.Metode Penelitian Pendekatan Kuantitatif Kualitatif Dan $R$ \& D. Bandung: Alfabeta.

Suryono, Yoyon, and Entoh Tohani. 2016. Inovasi Pendidikan Nonformal. Yogyakarta: Graha Cendikia.

Syaibany, Omar Mohammad Al Toumy Al. 1979. Filsafat Pendidikan Islam. Jakarta: Bulan Bintang.

Tafsir, Ahmad. 2010. Ilmu Pendidikan Dalam Persepektif Islam. Bandung: Remaja Rosda Karya.

2014 Ilmu Pendidikan Islam Dalam Perspektif Islam. Bandung: PT Remaja Rosdakarya.

Tim Penyusun. 1999. Kamus Besar Bahasa Indonesia. Jakarta: Balai Pustaka.

UU Sisdiknas RI. 2003. Undang-Undang Republik Indonesia Nomor 20 Tahun 2003 Tentang Sistem Pendidikan Nasional. Jakarta. 
Puspo

(WFS) Inisial. 2018 Wawancara. June 11.

Winardi, Joseph. 2006. Teori Organisasi Dan Pengorganisasian. Raja Grafindo Persada. 